\title{
CONDITIONAL DEFERRAL (AND WITHDRAWAL) OF CRIMINAL PROSECUTION FROM NATIONAL AND COMPARATIVE LEGAL PERSPECTIVE****
}

Summary: $\quad$ Conditional deferral (and withdrawal) of criminal prosecution is a typical institution of negotiated criminal justice. It is usually applied in relation to less serious criminal offences with the aim to relieve the court system workload and humanise the treatment of the offender. This institution was introduced into the Croatian criminal justice system more than 20 years ago. Despite such a long presence within the system, it has never acquired the status of an important and widely applied institution. Quite the contrary, its application in practice is quite scarce. In order to identify possible reasons for this at the normative level, the authors have undertaken a comparative legal analysis of said institution. Main characteristics of conditional deferral (and withdrawal) of criminal prosecution in Croatia have been compared with the main characteristics of identical or equivalent institutions in five other jurisdictions: Austria, Germany, Italy, England, and France. Special attention has been devoted to five highlighted issues: the goal(s) of the institution, the offences in relation to which it may be applied, the role of the court, the rights of the defendant, and the position of the victim.

Keywords: conditional deferral of criminal prosecution, diversion, informal sanctions

\footnotetext{
Zoran Burić, PhD, Assistant Professor, Faculty of Law, University of Zagreb, Trg Republike Hrvatske 14, 10000 Zagreb, Republic of Croatia. E-mail address: zoran.buric@pravo.hr. ORCID: https://orcid.org/0000-0001-5353-8478.

** Marija Pleić, PhD, Assistant Professor, Faculty of Law, University of Split, Domovinskog rata 8, 21000 Split, Republic of Croatia. E-mail address: marija.pleic@pravst.hr. ORCID: https://orcid.org/0000-0001-8868-0079.

*** Ivana Radić, PhD, Postdoctoral Researcher, Faculty of Law, University of Split, Domovinskog rata 8, 21000 Split, Republic of Croatia. E-mail address: ivana.radic@pravst.hr. ORCID: https://orcid.org/0000-0003-4946-6437.

**** This work has been fully supported by the Croatian Science Foundation under the project "Systematic approach to models of negotiated justice in Croatian criminal procedure" (IP-2019-04-1275).
} 


\section{INTRODUCTION}

Conditional deferral and withdrawal of criminal prosecution have been introduced into the Croatian criminal justice system more than 20 years ago. Despite the fact that this institution has been available to Croatian prosecutors for a considerable number of years, the statistics of its application in practice shows that it still has not established itself as an important institution within the Croatian criminal justice system. This institution has a threefold goal in Croatian law: the relief of court system workload through the reduction of the number of criminal cases that are brought before the courts and adjudicated before them; the humanisation of the criminal justice system through the deviation from the criminal procedure and the absence of the guilty judgement and the formal sanctioning of the offender; and pursuance of restorative justice goals through the decisive role of the victim within the institution. Due to its very limited application in practice, this institution has not significantly contributed to any of aforementioned objectives in the Croatian criminal justice system. This calls for a thorough re-examination of the institution of conditional deferral and withdrawal of criminal prosecution through its theoretical and normative analysis and the analysis of its practical application and the reasons for its scarce use in practice.

This paper represents a first step in the thorough re-examination of the institution and it is oriented towards theoretical and normative analysis of the institution in a comparative perspective. Theoretical foundations and normative framework of conditional deferral (and withdrawal) of prosecution in Croatian law are compared with the theoretical foundations and normative framework of comparable procedural institutions in five other countries: Austria, Germany, Italy, France, and England. The results of the comparative analysis are used to identify similarities and differences in Croatian and other criminal justice systems, especially in relation to five highlighted issues: the goal of the institution, the offences in relation to which the institution may be applied, the role of the court, the defendant's position and rights, and the role of the victim. The findings of the comparative analysis are used to identify issues which need to be further analysed and which shall be used as a basis for empirical analysis to be undertaken as the second step of the research. These issues that require further analysis are represented in the conclusion.

\section{CONDITIONAL DEFERRAL AND WITHDRAWAL OF CRIMINAL PROSECUTION IN CROATIAN LAW}

The institution of conditional deferral of criminal prosecution is currently regulated in Art. 206d of the Croatian Criminal Procedure Act (further in text: CPA). ${ }^{1}$ It represents one of the statutory forms of negotiated justice. It also represents an exception from the principle of mandatory prosecution, which dominates the Croatian criminal procedure and which obliges the state attorney to initiate criminal proceedings in all the cases where there is reasonable

1 Official Gazette, No. 152/08, 76/09, 80/11, 91/12 - Decision and Ruling of the Constitutional Court of the Republic of Croatia, $143 / 12,56 / 13,145 / 13,152 / 14,70 / 17$, and 126/19. 
doubt that a criminal offence prosecuted ex officio has been committed. In cases of conditional deferral, the opposite principle is applied, i.e. the principle of discretionary prosecution. This means that the state attorney is entitled by the statute not to initiate criminal proceedings although there is reasonable doubt that a criminal offence prosecuted ex officio has been committed. However, the state attorney may act in this way only if all the statutory prescribed conditions, which are presented and analysed further in the paper, have been met.

This institution was, for the first time, introduced into the Croatian criminal procedural legislation in the CPA from 1997, ${ }^{2}$ namely Art. 175. Pursuant to para. 1 of said Article, the state attorney was entitled to postpone the initiation of the criminal prosecution if the criminal charges have been filed in relation to a criminal offence of a lower degree of guilt in which the absence or insignificance of harmful consequences did not justify the public benefit of criminal prosecution. The scope of criminal offences in relation to which this institution may be applied was not quantitatively limited, i.e. it was not limited to criminal offences punishable by a penalty of a certain level of gravity. Rather, it was limited qualitatively, by referring to the level of guilt of the suspect and the gravity of the consequences of the offence. The decision of the state attorney to postpone the initiation of the criminal prosecution was conditioned upon the consent of the suspect and his/her willingness to meet one or more obligations foreseen by the statute. The CPA provided for a limited list of obligations by offering the following five: 1) committing an act for the purpose of repairing or compensating the damage caused by a criminal offence, 2) paying a certain sum of money in favour of a public institution, for humanitarian or charitable purposes, or to a fund for indemnification of victims of criminal offences, 3) meeting the obligation of statutory maintenance, 4) performing community service at liberty, and 5) subjecting oneself to drug or other addiction withdrawal in accordance with special regulations. The application of this institution presupposed a negotiated agreement between the state attorney and the suspect. However, such an agreement, in order to produce legal effects, required the approval of the court (Art. 175, para 2 and 3 CPA). If and only after the suspect has fulfilled all the obligations arising from the agreement with the state attorney, the state attorney was legally obliged to dismiss the crime report (Art. 175, para 5). The possibility to conditionally defer the criminal prosecution following the agreement with the accused and the consent of the court was available to the state attorney also after he/she had already filed an indictment, during the stage of pre-trial (preliminary) examination of the indictment (Art. 273, para 3).

The first key changes to this institution have been introduced with the amendments of the CPA which were adopted in $2002 .^{3}$ Firstly, a quantitative limitation has been introduced in relation to the scope of the criminal offences to which this institution may be applied, i.e. it could be applied only to criminal offences punishable by a fine or imprisonment for a term not exceeding three years. Qualitative precondition is still applicable. ${ }^{4}$ Secondly, the court has been excluded from the agreement between the state attorney and the suspect. Such an agreement, in order to produce legal effects, does not require the approval of the court. ${ }^{5}$ Thirdly, an injured party has

2 Official Gazette, No. 110/97.

3 Official Gazette, No. 58/02.

4 However, it has been slightly changed: an offence of a lower degree of guilt in which the scale of the harmful consequences does not dictate the public benefit of criminal prosecution.

5 Although this seemed like a very important precondition for the application of the institution from the theoretical perspective, in practice judicial control over the agreements concluded between the state attorney and the suspect did not have any real 
been included into the agreement. The agreement shall not produce legal effects unless there is a prior consent of the injured party. This applies, of course, only to those criminal offences where there is an injured party. ${ }^{6}$ Fourthly, one more obligation has been added to the statutory list: subjecting oneself to psychosocial therapy in order to eliminate the violent behaviour without leaving the familial community or with the consent of the suspect to leave the familial community during therapy. Fifthly, the temporal scope of application has been broadened. Conditional deferral of criminal prosecution may take place before the trial has started (Art. 291, para 3).

New CPA from $2008^{7}$ has not significantly amended the institution. Neither have all the subsequent (eight) amendments to the CPA. However, some changes have taken place. There are three that deserve to be mentioned here. Firstly, the scope of criminal offences in relation to which this institution may be applied has been broadened. It is now possible to apply this institution to all the criminal offences punishable by a fine or imprisonment for a term not exceeding five years. The qualitative criterion has been abandoned by the statute. ${ }^{8}$ Secondly, the temporal scope of application of the institution has been further broadened. It is now possible to conclude such an agreement before the end of the trial..$^{9}$ Thirdly, a maximum deadline within which the suspect's obligation must be met was introduced - it may not be longer than one year.

CPA does not specifically regulate the defence rights of the suspect or the accused who has been offered conditional deferral of criminal prosecution by the state attorney. Therefore, general rules pertaining to defence rights apply. Under Croatian law, any suspect has the right, from the earliest stages of the criminal proceedings, to commission the services of a defence attorney. Negotiations within the institution of conditional deferral are not foreseen as one of the cases of mandatory defence under the CPA, and the suspect (who has not been arrested) does not fall within the framework of legal aid in criminal proceedings. This may be seen as a problematic feature of conditional deferral of criminal prosecution under Croatian law.

The purpose of the institution is not statutorily regulated. However, it may be claimed that this institution in the Croatian criminal justice primarily has a legal-economic purpose, ${ }^{10}$ i.e. to relieve the criminal justice system of less severe cases that may be adequately tackled without resorting to a full criminal procedure. It also works in the interest of the offender by giving him/her the opportunity to resolve the situation arising from the criminal offence without a conviction or entry into the criminal record. Finally, it also serves the interests of the victim through the application of the obligations which are primarily oriented towards him/her (compensation of damages caused by the criminal offence, reconciliation with the offender, decisive role of the victim in the stipulation of the agreement) and not towards the public interest of criminal prosecution. ${ }^{11}$

effects, Sirotić, V., Uvjetna odgoda kaznenog progona punoljetnog počinitelja kaznenog djela, Hrvatski ljetopis za kazneno pravo i praksu, vol. 19, no. 1/2012, p. 172.

6 Ibidem, pp. 175-176.

7 Official Gazette, No. 152/08.

8 Although formally abandoned, the qualitative criteria still play an important role in the application of the institution in practice, Sirotić, op. cit. Note 5, p. 173.

$9 \quad$ Ibid., p. 174.

$10 \quad$ Ibid., p. 164.

11 Ibid. 
Notwithstanding its many advantages, this institution is rarely used in practice. In the period from 2008 to 2017, from 1.00 to $4.5 \%$ of the total number of dismissals of criminal charges have been based on this institution. In 2017, out of 15557 crime report dismissals in that year, only 260 (or 1.7\%), were based on Art. 206d CPA. ${ }^{12}$ The duration and complexity of the procedure usually account for such scarce application of this institution in practice. ${ }^{13}$

\section{COMPARATIVE LEGAL ANALYSIS}

\subsection{GERMANY}

The German criminal procedure legislation and theory still advocate the principle of seeking material truth and principle of legality but, over the years, the consensual forms have also been introduced into the German criminal procedure. ${ }^{14}$ In Germany, the principle of legality (Legalitätsprinzip) is still the fundamental principle for prosecutors. ${ }^{15}$ This principle also has an opposite side, the principle of discretion (Opportunitat), and one of the forms of this principle is a conditional deferral of criminal prosecution. This institution has been introduced into the German criminal procedure in 1975 as part of legislative reforms with an objective to achieve procedural economy ${ }^{16}$, expedite criminal proceedings and ensure humanisation of the proceedings for the defendant in order to avoid his/her stigmatisation. ${ }^{17}$

In the case of the defendant charged with a misdemeanour (Vergehen), ${ }^{18}$ if the degree of guilt of the defendant is significantly reduced (geringe Schuld) and if the criminal prosecution in that case is not in the public interest (öffentliches Interesse an der Verfolgung), the Public Prosecutor's Office can dismiss the case with the consent of the defendant and the court competent for ordering the opening of the main case and impose conditions and instructions upon the defendant. ${ }^{19}$

12 Report of the State Attorney`s Office of Croatia for 2017, p. 36, available at: http://www.dorh.hr/dorh07062018 (accessed January 5, 2021). In comparison, in the practice of the Croatian Juvenile criminal procedure, unconditional and conditional deferral of prosecution is used to a much greater extent, i.e. in about $50 \%$ of cases. See: Radić, I., Sustav maloljetničkih sankcija, doctoral thesis, Pravni fakultet Sveučilišta u Zagrebu, Zagreb, 2016., p. 305-309.

13 Sirotić, op. cit. Note 5, pp. 169-170.

14 Boyne, S., Procedural Economy in Pre-Trial Procedure: Developments in Germany and the United States (October 23, 2013, last revised December 1, 2015), Indiana University Robert H. McKinney School of Law Research Paper No. 2013-39, p. 335.

$15 \S 152$ German Code of Criminal Procedure, hereinafter D-CCP (Strafprozeßordnung (StPO) as published on 7 April 1987 (Official Gazette I, p. 1074, 1319), last amended by Article 49 of the Act from 21 December 2020 (Official Gazette I, p. 3096).

16 Boyne, S., op. cit. Note 14, p. 335-341.

17 One of the crime prevention policy goals is to avoid formal criminal procedure especially with first-time offenders in the cases of less serious offences. The complete clarification of the facts and passing of a merit judgment in those cases was seen as neither necessary nor particularly desirable. Krstulović, A., Nagodbe stranaka u suvremenom kaznenom postupku, Hrvatsko udruženje za kaznene znanosti i praksu, Kaznenopravno-kriminalistička biblioteka Vladimir Bayer, Zagreb, 2007, p. 94-95.

18 Misdemeanours (Vergehen) are criminal offences that are punishable with a sentence of up to 1 year of imprisonment or by a fine. (§12(2) DCC. German Criminal Code (Strafgesetzbuch) as published on 13 November 1998 (BGBl. I S. 3322), last amended by Article 1 of the Act from 30 November 2020 (BGBl. I S. 2600).

$19 \S 153 \mathrm{a}(1) \mathrm{D}-\mathrm{CCCP}$. Many authors believe that the legal definitions of a lower degree of guilt and the lack of public interest are vague and their interpretation in different cases leaves the prosecutor with a wide range of discretionary powers. That is why many German states have issued the guidelines for prosecutors in order to achieve a more unified application of §153a D-CCP in 
The prosecutor can impose conditions and instructions (Auflagen und Weisungen) upon the defendant that must be fulfilled within a specific period of time, i.e. a maximum of six months or a maximum of one year. ${ }^{20}$ One of the conditions that can be imposed upon the defendant is that he/she is obligated to participate in the Victim-Offender Mediation (VOM) and/or indemnify the victim. VOM is specific because the prosecutor and the court have the obligation to examine, at every stage of the proceedings, whether it is possible to reach a mediated agreement between the accused and the victim. The defendant should be the first to voluntarily propose such an agreement to the prosecutor as a token of his/her restorative efforts towards the victim. ${ }^{21}$ This agreement cannot be accepted against the express will of the victim and this is the only condition where that is necessary. ${ }^{22}$

In order to impose conditions and instructions, it is required to obtain the consent of the defendant and the court competent for ordering the opening of the main case. The court's approval is required under the same condition as with the unconditional deferral of prosecution. ${ }^{23}$ The victim`s consent is not necessary. During the criminal proceedings, the victim has the right to be notified about the dismissal of the case and the outcome of the court proceedings, as well as to be assisted by an attorney. ${ }^{24}$ In the cases of deferral of prosecution, the victim has no right to file an appeal against the decision of the prosecutor. ${ }^{25}$

After the public charges have already been preferred, the competent court can also make a decision based on the conditional deferral of prosecution and impose the same conditions or instructions upon the defendant but only with the consent of the prosecutor and the defendant. ${ }^{26}$

When the defendant complies with the conditions and instructions, it is no longer possible to reopen the case because of the principle of ne bis in idem and the prosecutor will make a final decision to waive the prosecution. The case can be reopened only if it seems that the criminal offence in question was not a misdemeanour but a felony. ${ }^{27}$.

\subsection{AUSTRIA}

Diversion measures were implemented into the Austrian Code of Criminal Procedure (A-CCP) Strafprozessordnung (StPO) ${ }^{28}$ with the new Strafprozessreformgesetz (BGBI I 2004/19)

practice. Gillièron, G., Public Prosecutors in the United States and Europe, A Comparative Analysis with Special Focus on Switzerland, France, and Germany, Springer International Publishing, 2014, p. 271.

$\S 153 \mathrm{a}$ (1) D-CCP.

21 Gillièron, G., op. cit., Note 19, p. 271-272.

$22 \S 155 a \mathrm{D}-\mathrm{CCP}$.

23 Gillièron, G., op. cit. Note 19, p. 270, 274.

$24 \S 406 \mathrm{~d}-4061 \mathrm{D}-\mathrm{CCP}$.

25 Victim can file a complaint with a superior prosecutor (Dienstaufsichtsbeschwerde). Gillièron, G., op. cit. Note 19, p. 269.

$26 \S 153 a(2)$ D-CCP.

27 Gillièron, G., op. cit. Note 19, p. 274.

Strafprozessordnung (StPO) 1975, BGBl. Nr. 631/1975 (WV), the latest amendment BGBl. I Nr. 24/2020. 
in 2004 that has been in force in Austria since 1 January 2008. ${ }^{29}$ One of the measures introduced with this act was the conditional deferral of prosecution or so called diversion (Rücktritt von der Verfolgung-Diversion) that is regulated in section XI, § 198-209b of the A-CCP.

In Austria, diversion refers to a premature termination of criminal proceedings by the prosecutor or the court in minor or less severe offences cases and it is possible from the moment the prosecutor has been acquainted with the criminal offence until the end of the main trial. ${ }^{30}$ The prosecutor has the right to impose different alternative measures upon the defendant in order to defer prosecution. The aim of diversion is to avoid unnecessary stigmatisation of the defendant, to achieve economy in criminal proceedings but, at the same time, to account for the interests of the victim, especially regarding the compensation of damages. ${ }^{31}$

The Public Prosecutor's Office can propose to impose one of four alternative measures to the defendant in order to defer prosecution in cases when: the public prosecutor deems that the circumstances of the case are clear and the defendant is the likely perpetrator of the criminal offence in question; the suspension of the proceeding according to $\$ 190-192 \mathrm{~A}-\mathrm{CCP}$ is not an option; a traditional criminal sanction is not required in the interest of special and general prevention; the criminal offence in question falls under the jurisdiction of the district court or of the sole judge at the regional court (Landsgericht), which means that the criminal offence is not sanctioned with a sentence of more than five years of imprisonment, the guilt of the defendant is not regarded as serious ( $\$ 32 \mathrm{StGB}$ ), the criminal offence did not result in the death of a person. ${ }^{32}$

The defendant must be informed by the prosecutor about his/her rights during this process, about the conditions for the deferral of prosecution, about the requirement of his/her consent that must be given voluntarily and about the fact that he/she has the right to request a continuation of the criminal proceedings. ${ }^{33}$

The Austrian legislator has clearly stated that during diversion the victims' rights must be protected to the greatest possible extent. The victim must be fully informed about his/her rights during this procedure in accordance with $\S 70$ (1) A-CCP. Before making a decision about the deferral of prosecution, the victim must be heard if it appears necessary to safeguard their interests and rights, in particular those of indemnification. In any case where the defendant has declared that he/she is ready to compensate the damages caused by the criminal offence, the victim must always be informed. The same applies in situations where the defendant assumes an obligation that directly affects the interests of the victim. ${ }^{34}$ The victim has no right to file an appeal against the decision made by the prosecutor. ${ }^{35}$

\footnotetext{
29 Carić, M., Skraćeni oblici kaznenog postupka, dokorski rad, Pravni fakultet Sveučilišta u Splitu, Split, 2012, p. 269.

30 Tak, P.J.P., Methods of diversion used by the prosecution services in the Netherlands and other Western European Countries, 135th International senior seminar visiting experts` papers, Resource material series No. 74., 2008, p. 63.

31 Carić, M., op. cit. 29, Note, p. 269.

$32 \S 198$ (1), (2) A-CCP. Carić, M., op. cit. Note 29, p. 271.

$33 \S 207 \mathrm{~A}-\mathrm{CCP}$

$34 \S 206$ A- CCP. See: Krstulović, A., op. cit. Note 17, p. 119-120.

35 Carić, M., op. cit. Note. 29, p. 272.
} 
The public prosecutor can impose one of the four measures upon the defendant: a settlement of a fine, community service, probation, and Victim-Offender Mediation (VOM). ${ }^{36}$

In cases when the defendant is not willing to accept the proposal from the prosecutor regarding the deferral of prosecution and requests that the criminal proceedings against him/ her be continued, the prosecutor must continue with the proceedings. If the defendant has successfully met the imposed measures and the prosecutor has dismissed the case, the reopening of criminal proceedings is possible only under the conditions of regular retrial. ${ }^{37}$ The prosecutor will continue with the criminal proceedings if the defendant has not entirely or in time met the obligations imposed upon him/her or if during the probation period another criminal proceeding has been initiated against the defendant. ${ }^{38} \mathrm{After}$ the indictment has been filed, the Public Prosecutor's Office cannot impose the diversion measures upon the defendant independently, but can only submit an appropriate request with the court. In that case, the court has the right to make a decision until the end of main hearing about the deferral of prosecution and to impose diversion measures upon the defendant. The prosecutor has the right to make an appeal against the decision of the court. ${ }^{39}$

\subsection{FRANCE}

An institution very similar to conditional deferral of criminal prosecution also exists in the French criminal procedural law. It was introduced in 1999 and is regulated in Arts. 41-2 and 41-3 of the Code of Criminal Procedure (Code de procédure pénale). This institution, known as composition pénale, allows the prosecutor not to initiate the criminal proceedings against the suspect, if the suspect admits the criminal offence and is ready to execute one or more measures which are proposed to him/her by the prosecutor..$^{40}$ Due to the fact that the suspect needs to admit the offence, this institution comes close to a plea bargain and has therefore been described as the first iteration of the plea bargain within the French criminal justice system. ${ }^{41}$ The similarities do not stop there. A composition pénale enters the criminal record of the suspect. ${ }^{42}$ However, the most important point of deviation from the plea bargain model is the fact that there is no guilty judgement. ${ }^{43}$ In fact, there is no criminal procedure against the

$36 \S 200-204$ A-CCP. Victim`s consent is an essential precondition for VOM but it is not necessary if it is refused on the grounds that are not to be taken into consideration within the criminal proceedings, like retribution or revenge. Tak, P.J.P., op. cit. Note 30, p. 64.

$\S 205$ (1) A-CCP. Reopening of a case is possible only if there is a big difference (in criminal sentence) between the criminal offence that was a basis for diversion measures and the incriminating criminal offence.

40 Hodgson, H., Guilty Pleas and the Changing Role of the Prosecutor in French Criminal Justice, in Luna, E., Wade, M. (eds.), The Prosecutor in Transnational Perspective, Oxford University Press, 2012, p. 125.

41 Coscas-Williams, B., Alberstein, M., A Patchwork of Doors: Accelerated Proceedings in Continental Criminal Justice Systems, New Criminal Law Review, vol. 22, no. 4/2019, p. 600.

42 Hodgson, J., op. cit. Note 40, p. 126. 
suspect. Hence, some authors conclude that the purpose of this institution is to decriminalise minor offences. ${ }^{44}$

The agreement between the prosecutor and the suspect must be concluded in writing and the suspect must be informed that he/she has the right to consult an attorney before agreeing to the proposed measure. ${ }^{45}$ Composition pénale does not foresee the possibility of negotiations between the prosecutor and the suspect. ${ }^{46}$ On the contrary, the suspect is given 10 days to accept or reject the offer of the prosecutor. ${ }^{47}$ This procedure is possible only in relation to offences which are punishable by a fine or imprisonment of up to 5 years. ${ }^{48}$ It can also be applied in relation to all contraventions. ${ }^{49}$ There is a whole spectrum of measures that can be offered to the suspect by the prosecutor, including to settle a fine, hand over the item used or intended to be used for committing the offence or that results from the offence, relinquish the driving license for a maximum period of 6 months, or perform unpaid community service for the maximum period of 60 hours. ${ }^{50}$ Significant attention is devoted to the interests of the victim. If the victim has been identified, the prosecutor must propose to the offender to compensate the damages caused by the offence, unless the offender can show that the damages have already been compensated. ${ }^{51}$ The victim must be informed thereof and the suspect must fulfil this obligation within the period of 6 months. ${ }^{52}$

The agreement between the prosecutor and the suspect must be validated by the court. ${ }^{53}$ The court, before validating the agreement, needs to speak with the suspect and, if deemed necessary, with the victim, ${ }^{54}$ who may both be assisted, where necessary, by their respective attorneys. ${ }^{55}$ If the suspect complies with the agreement, there will be no criminal proceedings. However, if the suspect does not comply with the agreement, the prosecutor shall decide what further actions to take ${ }^{56}$ including the possibility of a criminal prosecution.

This procedure is often used in the French judicial practice and has significantly increased the powers of the prosecutor in the pre-trial proceedings. ${ }^{57}$ This procedure enables the prosecutor to deal more effectively with petty offencesless severe cases. ${ }^{58}$ However, defence attorneys may have a different viewpoint of this institution. Some of them have claimed that there

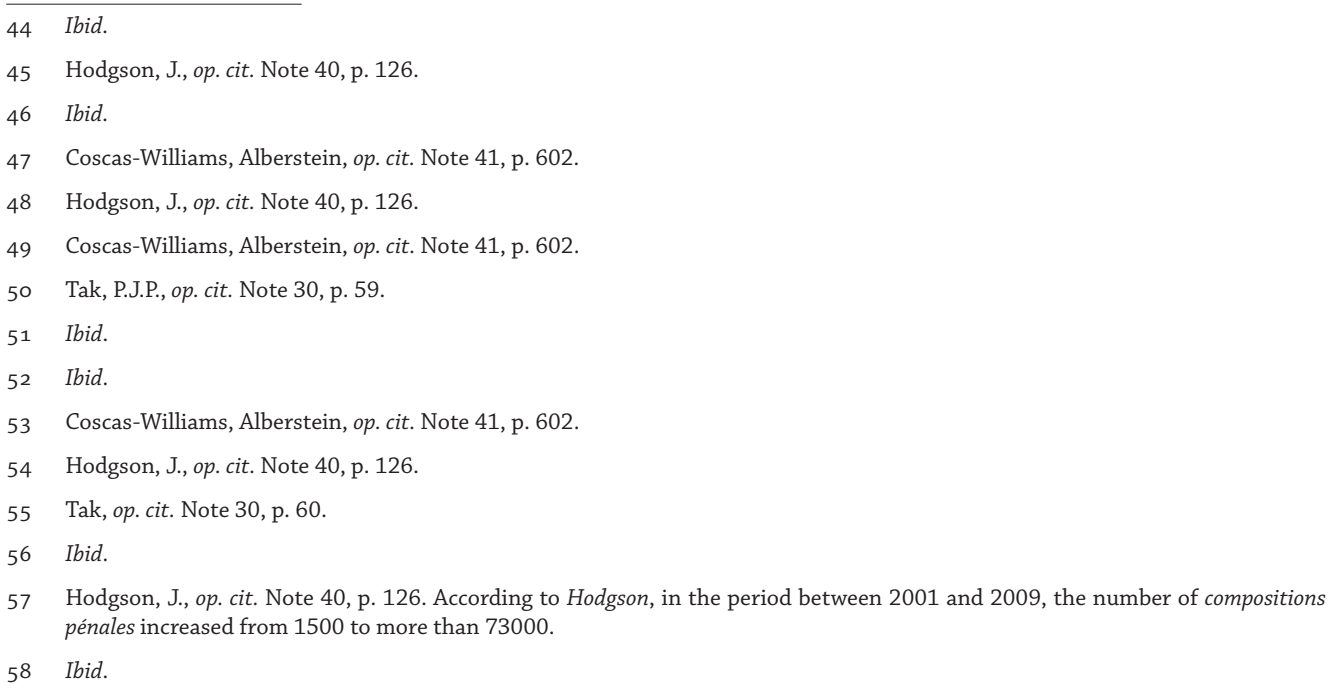


is no real option for the suspect who has been offered a composition pénale, since it is difficult for him/her to refuse the prosecutor's offer. ${ }^{59}$

\subsection{ITALY}

The legality principle and the mandatory prosecution in Italy have been elevated to the constitutional level and as such leave no discretion to the public prosecutor to either suspend or withdraw an action, which must result in a judicial decision. ${ }^{60}$ Yet, in practice, the discretion in making a decision about charging the accused is exercised by waiting for the maximum amount of time to elapse in which a preliminary investigation can take place, followed by filing a dismissal request to the court. ${ }^{61}$ Even though the principle of legality leaves no space for the forms of diversion exercised by the public prosecutor, the Italian legislator has introduced some similar forms. The first steps were made in 1988 in relation to juveniles. ${ }^{62}$ In 2000 , the institutions of acquittal in the cases of particularly low gravity offences (particolare tenuità del fatto) and extinction of the offence in the cases of compensation or restitution of damages (Estinzione del reato conseguente a condotte riparatorie) for adult offenders were introduced within the competence of the justices of the peace (giudice di pace). ${ }^{63}$ The latter implies consent and active participation of the defendant. ${ }^{64}$ The justice of the peace, after hearing the parties and any injured person, declares the offence extinguished, when the defendant demonstrates that he/she has undertaken concrete measures to repair the damages caused by the offence before the first hearing or within a period not exceeding three months after the first hearing. If the judge does not declare the offence extinguished, he/she will order the continuation of the proceedings. Although the offence can only be declared extinguished after the parties have been heard, the role of the victim is diminished to the extent that the victim's opinion is not binding and the victim has no right to challenge the decision. ${ }^{65}$

In 2014, the suspension of the proceedings pending probation (Sospensione del procedimento con messa alla prova dell'imputato) was introduced within Art 168-bis of the Criminal Code $(C C)^{66}$ for the offences punishable by a fine or/and with the penalty of imprisonment not ex-

59 Ibid.

60 Caianiello, M., The Italian Public Prosecutor: An Inquisitorial Figure in Adversarial Proceedings? in: Luna, E.; Wade, M. (eds), Transnational perspectives on prosecutorial power, Oxford University Press, 2011, p. 4-6., Available at SSRN: https://ssrn.com/ abstract=1976204. Accessed on 28 December 2020.

61 Ibid., p. 11.

62 Ruggieri, S., Audi Alteram Partem in Criminal Proceedings, Towards a Participatory Understanding of Criminal Justice in Europe and Latin America, Springer International Publishing AG, 2017, p. 34. Ruggieri, F., Marcolini, S., Italy in: Toward a Prosecutor for the European Union, Volume 1: A comparative Analysis. Ed. Katalin Ligeti. London: Hart Publishing, 2013, pp. 393-394.

63 Art 35 Decreto Legislativo 28 agosto 2000, n. 274, "Disposizioni sulla competenza penale del giudice di pace, a norma dell'articolo 14 della legge 24 novembre 1999, n. 468", pubblicato nella Gazzetta Ufficiale n. 234 del 6 ottobre 2000 - Supplemento ordinario n. 166.

Ruggieri, S., op. cit. Note 62, pp. 35-36. Ruggieri, F.; Marcolini, S., op. cit. note 62, pp. 393-394.

64 Ruggieri, S., op. cit. Note 62, p. 35.

65 Ibid.

66 Legge 28 aprile 2014, n. 67. Codice Penale 2020: aggiornato con le ultime modifiche legislative introdotte, da ultimo, dalla L. 14 agosto 2020, n. 113 e dal D.L. 16 luglio 2020, n. 76 (Decreto Semplificazioni);" (R.D. 19 ottobre 1930, n. 1398). 
ceeding a maximum term of four years. ${ }^{67}$ The accused may request the suspension of proceedings pending probation either before the conclusion of the intermediate phase or prior to the opening of the first-instance direct trial and the proceedings with a direct summons for trial. ${ }^{68}$ If the request is submitted during preliminary investigations, the public prosecutor's consent is required. ${ }^{69}$ The court decides after hearing the victim and the parties. The accused and the public prosecutor can challenge the order before the Court of Cassation and the victim may file a motion for appeal or appeal the order independently if he/she has not been informed of the hearing or not heard. After the suspension of proceedings pending probation, the court sets the hearing for evaluation and either declares by judgment that the offence is extinguished or directs by order that the trial be resumed. ${ }^{70}$

Even though the victim must be heard before ordering the probation period, their position is still rather weak. The victim's opinion is not required in the cases of modifying the original rules during the probation period and, what is more, although the victim must be summoned to the hearing at the end of the probation period, their role at the hearing remains unclear. ${ }^{71}$

Recently, Orlando Reform from 2017, introduced within Art. 162 ter of CC institution of extinction of the offence following the remedial proceedings (Estinzione del reato per condotte riparatorie) was inspired, inter alia, by aforementioned institutions. The purposes of this legislative amendment were aimed towards a reasonable duration of the proceedings, the deflation of the proceedings, ${ }^{72}$ the settlement of conflicts of a predominantly private character, and the incentive to satisfy the victim's compensation claims. ${ }^{73}$ In the cases of proceedings following the victim's complaint, the judge declares the offence extinct after hearing the parties and the injured person if the accused has fully repaired, within the maximum prescribed term from the opening of the first instance trial, the damage caused by the crime through restitution or compensation and eliminated, where possible, the harmful or dangerous consequences of the crime. Art. 162 ter is applicable only to crimes prosecutable upon a complaint filed by the injured party which is subject to a withdrawal. It has been argued that the scope of application of Art 162 ter is too narrow ${ }^{74}$ and that it would be specifically applicable only when the victim does not intend to accept the defendant's offer, but the judge, considering it however congruous, surpasses the contrary will of the victim. ${ }^{75}$

67 Ruggieri, S., op. cit. Note 62, p. 38

68 Art 464 bis Code of Criminal Procedure (CCP). Codice di Procedura Penale (Testo coordinato ed aggiornato del D.P.R. 22 settembre 1988, n. 447) Aggiornato al D.L. 17 marzo 2020, n. 18.

69 Art 464-ter CCP.

70 Art 464-septies CCP.

71 Ruggieri, S., op. cit. Note 63, p. 38.

72 The need for a procedural deflation arose from the real emergency constituted by prison overcrowding and by the increasing number of proceedings. Caporotundo, F., L'estinzione del reato per condotte riparatorie: luci ed ombre dell'art. 162-ter c.p., Archivio penale, 2018, n. 1, p. 2.

Ferrione, M., L'estinzione del reato per condotte riparatorie art. 162 ter c.p., p. 2. https://www.studiolegalecavallo.com/wp-content/ uploads/2018/07/slide-162-ter-Convegno-3_optimize.pdf, p. 7. Accessed on 28 December 2020.

Cascini, D. N., Il nuovo art. 162-ter c.p.: esempio di "restorative justice" o istituto orientato ad una semplice funzione deflattiva?, Archivio penale, n. 2, 2017, p. 7. 


\subsection{ENGLAND}

In 2003, the English criminal justice system introduced the institution of conditional cautioning under sections 22 to 27 of the Criminal Justice Act. ${ }^{76}$ It is defined as a caution containing conditions which the offender must comply with, and it represents a statutory development of the non-statutory, 'simple' caution, which has long been available at the discretion of the police. ${ }^{77}$ Originally, the Crown Prosecutor decided on the conditional caution following a consultation with the police, and since 2012 the police can issue the conditional caution on its own except for indictable-only offences where the CPS's authorisation is still required. ${ }^{78}$

Consensual character of this institution is evident from section 23(5) which requires the offender's consent to be offered conditional caution. CJA lists the following requirements for applying this institution: the existence of sufficient evidence to charge the offender, offender`s confession and signed document containing consent, conditions attached to caution and its effects. ${ }^{79}$ In deciding that there is sufficient evidence to charge the offender with the offence, the Full Code Test must be applied; it consists of the evidential and public interest phase. When the conditional caution is ordered, the criminal proceedings are halted while the offender complies with the conditions, in which case the prosecution has usually not been initiated. Where there is no reasonable excuse for non-compliance, the criminal proceedings may be initiated and the conditional caution ceases to have effect.

The objectives of the conditions attached to the conditional caution are rehabilitation, reparation, punishment and special objectives in relation to a foreign offender. ${ }^{80}$ The Code of Practice for Adult Conditional Cautions (CPACC) from 2013 elaborates in detail the types of the attached conditions which must be appropriate, proportionate and achievable. ${ }^{81}$ The Director of Public Prosecutions Guidance furthermore explains the cases in which the conditional caution may be considered. ${ }^{82}$

One of the main purposes of the conditional caution is to offer proportionate response to low level offending and it is usually not appropriate for serious offences. The authorised person may offer conditional caution for summary-only and either-way offences. For serious either-way offences, it may only be offered to foreign offenders, and for indictable-only offences only in the most exceptional circumstances where the decision must be approved by a Deputy Chief Crown Prosecutor. ${ }^{83}$

76 Criminal Justice Act 2003 (CJA), https://www.legislation.gov.uk/ukpga/2003/44.

77 Pierpoint, H., Bennett, T., Evaluation of conditional cautioning: surveys of stakeholders, offenders and victims, 1st February 2005, pp. 10 - 11. https://pure.southwales.ac.uk/en/publications/evaluation-of-conditional-cautions-surveys-of-stakeholders-offendersand-victims(c47023b9-7d52-492d-b522-6d8dd3dc2f5d).html. Accessed on 28 December 2020. University of Warwick, School of Law Université Lumière Lyon 2, Faculté de droit et de science politique, December 2015 , p. 113.

81 Code of Practice for Adult Conditional Cautions: part 3 of the Criminal Justice Act 2003, January 2013.

82 Conditional Cautioning: Adults - DPP Guidance, Updated 01 November 2019 Legal Guidance.

83 14.1-14.4 DPP Guidance. 
Even though the CJA prescribes the obligation to consult the victim when deciding whether the conditional caution is appropriate and in determining suitable conditions, the victim's consent does not represent a constitutive precondition. ${ }^{84}$ Depending on the victim's consent, the conditions including direct reparation may be ordered. In any case, the victim must be informed of the outcome of the case.

There are some procedural guarantees for the defendant attached to the conditional caution. The offender has the right to a free legal consultation regarding the rights of which he/ she must be informed before administering the conditional caution, he/she must be informed of the evidence against him/her, of all the effects of conditional caution, including that conditional caution will form part of his/her criminal record. The authorised person must ensure that the offender understands the consequences of failing to comply with the conditional caution, in particular that he/she may be liable for arrest and prosecution for the original offence. ${ }^{85}$ In order to minimise the risk of a renewed prosecution being stayed as a form of abuse of the process, it must be ensured that the person is informed that the caution may not preclude a subsequent prosecution and that it will not preclude a civil action by the aggrieved party. ${ }^{86}$ If the offender fails to comply with the conditions, the document signed by the offender is admissible in the subsequent proceedings, except when it has been rescinded for other reasons. ${ }^{87}$

As evident from the case law, the decision on the conditional caution may be judicially reviewed. If proved to be unlawful, either because the proper procedures have not been followed or because it has been given in respect of an offence that is outside of scope of the Director's Guidance, or because it is otherwise evidently unreasonable, the decision to authorise and then administer the conditional caution may be quashed and the caution set aside. ${ }^{88}$

\section{DISCUSSION ON KEY ASPECTS OF THE CONDITIONAL DEFERRAL OF CRIMINAL PROSECUTION}

\subsection{THE OBJECTIVES}

The legislators in all countries explained their actions, this new wave of legislative amendments in the general criminal procedure legislation, almost uniformly with the same reasons that they have to find a new way of dealing with the criminal courts overburdened by case load in order to expedite criminal proceedings and ensure a more efficient criminal justice system. "There are simply too many offences, too many offenders and two few resources to deal with them all" ${ }^{89}$ In many cases, the efficiency and the need to solve the case in the quickest possible

\footnotetext{
84 S. 2.47 CPACC.

85 3.5-3.9 CPACC.

86 DPP Guidance, Annex D: Conditional Cautioning - Incorrect or Inappropriate Decisions.

87 Ibid. Art 24(2) CJA.

88 DPP Guidance.

89 Coscas-Williams, B., Alberstein, M., op. cit. Note 41, p. 587.
} 
way results in a more bureaucratised and standardised procedure where the individuality of the specific case is lost and neglected..$^{90}$ Apart from that, the legislators usually try to achieve some other objectives with the application of this institution. In France, one of the aims of conditional deferral of prosecution is the decriminalisation of minor offences, while England is the only country that mentions rehabilitation and the use of this institution in relation to foreign offenders. This institution is often seen as a good way of dealing with the first-time offenders in the cases of less serious criminal offences where the complete clarification of the facts and passing of a merits judgment is not seen as either necessary or desirable (Germany) ${ }^{91}$ or is used to solve the conflicts of a predominantly private character (Italy). This shows that in the cases of less serious criminal offences the state is more interested in efficiency and reducing the costs of proceeding than finding material true and conducting a transparent criminal proceeding with all fair trial guarantees. ${ }^{92}$ In order to achieve a more organised criminal justice system, a better use of resources and people working in the judiciary and to put focus on more serious criminal offences that the public is usually more concerned with, petty offences must be resolved in a more efficient way with the use of new diversion measures.

From the offender's point of view, this institution gives them an opportunity to avoid formal criminal proceeding and all its side-effects, including stigmatisation. For the defendant, there is no formal conviction and no entry into criminal records (Croatia, Austria), but in France composition pénale enters the criminal record of the defendant.

One of the elements that can be found in all countries is the respect for the interest of the victims during this procedure, which means that this institution also meets the objectives of restorative justice and mediation. In addition, this institution has changed the role of the prosecutor in all countries, giving them a wide range of discretionary powers and making them the most important factor in achieving all these above-mentioned objectives.

\subsection{PRINCIPLE OF PROPORTIONALITY}

The use of conditional deferral of criminal prosecution in general is reserved for minor and less severe criminal offences in all observed countries. The best example of broadening the scope of application of this institution regarding the gravity of criminal offences can be seen in Croatia. Initially, the Croatian legislator decided not to limit the application of this institution quantitatively, but in the later years they decided to do so and put focus only on the gravity of the criminal offence in question (criminal offences punishable by a fine or imprisonment for a term not exceeding five years ${ }^{93}$ while completely disregarding the qualitative criteria that

90 Soubise, L., Guilty Pleas in an Inqusitorial Setting-An Empirical Study of France, Journal of Law and Society, Cardiff University law School, vol. 45, No. 3, September 2018, p. 412-415.

91 Krstulović, A., op. cit. Note 17, p. 95.

92 Ivičević Karas, E., Consensual Justice in Croatian Criminal Procedural Law: the Need for a Systematic Approach, EU and Comparative Law Issues and Challenges Series (ECLIC) - Issue 4 (2019), p. 12.

93 For comparison, from 1997, in the Croatian juvenile criminal procedure the application of conditional deferral of prosecution has been possible for the offences punishable with a fine or imprisonment for a term not exceeding five years. There have even been some proposals to broaden the scope of application of this institution onto a wider range of criminal offences but it was not accepted. See: Radić, I., op. cit. Note 12, pp. 314-324. 
can still be found in some comparative legislations (Austria, Germany). ${ }^{94}$ Almost all countries apply this institution to criminal offences that are punishable by a fine or sentence of up to five years of imprisonment (Croatia, France, Austria). ${ }^{95}$ Germany can be seen as an exception because the conditional deferral of prosecution can be applied in cases of Vergehen (misdemeanour), criminal offences that are punishable by no more than 1 year of imprisonment or by a fine. ${ }^{96}$ In England, this institution is reserved for low level offences (summary-only and either-way offences) and is considered inappropriate for serious offences. As it derives from above, in practice when applying diversion measures, the prosecutors usually make their decision through some type of a standardised procedure that is often formed some time after and in accordance with the guidelines they receive from their superiors which can result in the fact that certain types of criminal offences are excluded from the very beginning. ${ }^{97}$

\subsection{PROSECUTORIAL DISCRETION AND POWERS OF THE COURT}

Conditional deferral of criminal prosecution implies extension of prosecutorial discretion, but the degree of independence in exercising such discretion varies, and the prosecutor is allowed to make a decision either independently or with the formal consent of the court. ${ }^{98}$

In the Croatian criminal procedure law, this is one of the consensual forms that do not require judicial control..$^{99}$ It can be argued by the fact that the deferral of criminal prosecution is in favour of the defendant since he/she would otherwise be prosecuted in accordance with the principle of legality, ${ }^{100}$ and that the defendant does not have to plead guilty and it does not enter his/her criminal record. ${ }^{101}$ Finally, the judicial control which was previously foreseen in the CPA was a mere formality. Yet, the fact remains that the state attorney imposes the obligations similar to criminal sanctions and measures upon the defendant. ${ }^{102}$ The analysis of the relevant comparative systems indicates that most of them foresee some form of judicial control over the decision on the conditional deferral of criminal prosecution, ${ }^{103}$ though it is usually exercised pro forma. In fact, in Germany and France the prosecutor cannot impose

94 See part 3.1 and 3.2. In Croatia, qualitative criteria (lower degree of guilt and absence of harmful consequences) is still taken under consideration in practice by prosecutors when making their decision.

95 In Italy, this institution can be applied to offences punishable with a fine or/and with a penalty of imprisonment not exceeding a maximum term of four years.

96 Those offences in Germany include crimes of a moderate to high level of gravity.

97 Soubise, L., op. cit. Note 90, pp. 412-415.

98 Jehle, J. M., The Function of Public Prosecution within the Criminal Justice System Aim, Approach and Outcome of a European Comparative Study in: Jehle, J.M., Wade, M. (eds), Coping with Overloaded Criminal Justice Systems. The Rise of Prosecutorial Power Across Europe, Springer, 2006, p. $21-22$. See Ivičević Karas, E., op. cit. Note 92, p. 15.

100 Art 2(3) CPA. For comparison, composition pénal under French law and conditional caution under English law enters the criminal record.

102 It has been stated that the discretion to dispose of cases and impose sanctions free from considerable oversight leads to a quasijudicial function of prosecutors. Boyne, S., The German Prosecution Service, Guardians of the Law? Springer Berlin Heidelberg, 2014, p. 64. 
any conditions upon the accused without the consent of the court. The powers of the court in Austria are exercised only after the agreement between the parties following the filing of the indictment, while the German law envisages judicial competence at this stage of procedure through the prosecutor's consent. Even though the Croatian law prescribes the involvement of the court in the cases of conditional withdrawal of prosecution, when it takes place after the formal commencement of the proceedings, there is a substantive difference in the powers of the court in relation to the described comparative systems. ${ }^{104}$ In Croatia, a single judge does not decide on the withdrawal but is merely obliged to adjourn the proceedings upon the state attorney's statement on the conditional withdrawal of the charges. However, it has been argued in theory that there must be an exception to such an obligation in the situation when the judge finds that the requirements from Art. 206.d (1) CPA have not been met, ${ }^{105}$ even though the CPA does not refer to it at all. When the state attorney, following the fulfilment of the obligations by the accused, withdraws the charges, the judge has no option but to terminate the proceedings due to the absence of the request from the authorised prosecutor and in accordance with the accusatory principle. The criminal proceedings in these cases may be reopened in accordance with the provisions of the CPA on the reopening of the proceedings. ${ }^{106}$

Even though the question of adequacy and of the need for the introduction of judicial control should be further analysed in an empirical study, it could be debated whether the introduction of judicial control would further avert the state attorney from applying this institution, which is already very rarely applied due to the complexity of the procedure, especially in comparison with the application of a penal order which applies to the same category of offences, and whether the control (in a form of a consent) of the victim, on one side, and the defendant, on the other side, suffices.

\subsection{PROCEDURAL RIGHTS OF THE DEFENDANT}

Considering the powers and the discretion of the state attorney in deciding on the conditional deferral which are not followed by judicial control in the Croatian law as mentioned above, it is important that the defendant be guaranteed procedural rights which will enable $\mathrm{him} /$ her to make the right decision on the outcome of the proceedings in the situation of factual procedural inequality. ${ }^{107}$

The analysis shows that all comparative legal systems require the explicit consent of the defendant on the application of this consensual form before the decision to defer prosecution is made, but some even require the admission of guilt (England, France). The defendant must be informed of his/her rights, the course of the procedure and the effects of application of this institution on their position in the case.

104 Conditional withdrawal of criminal prosecution in this phase, after the commencement of the proceedings, is applied in practice even less frequently than conditional deferral of prosecution which takes place during the preliminary stage.

105 Glasnović Gjoni, V., Sirotić, V., Uvjetni odustanak od kaznenog progona i praksa Općinskog suda u Puli - Pola, Pravni vjesnik, 3-4/2016, p. 167.

106 Art 500(4) and 503(1) CPA.

107 For the objections to the concept of conditional deferral and its impact on the defendant $c f$. Sirotić, op. cit. Note 5, pp. 164 - 165. 
As regards Croatian law, all procedural rights guaranteed to suspects and accused persons under the CPA apply, to the same extent, to the procedure of conditional deferral. However it should be taken into consideration, whether explicitly prescribing in law the obligation to inform the defendant of the legal effects of his/her consent and state attorney's decision as well as of the effects of his/her failure to comply with the agreement would strengthen the procedural position of the defendant.

The defendant has the right of access to an attorney of which right he/she must be informed, but this situation does not fall under either the case of mandatory defence or free legal aid. ${ }^{108}$ Considering that mandatory defence for this category of offences is not foreseen even during the trial, there are no sufficient arguments to extend it onto conditional deferral. However, taking into account that the defendant is required to voluntarily consent to informal sanctions imposed by the state attorney, at least the right to a legal aid covered by the state budget funds should be considered.

\subsection{VICTIM'S RIGHTS}

In general, the victims of criminal offences are included in the processes necessary for the application of conditional deferral (or in certain jurisdictions also withdrawal) of criminal prosecution. However, the degree and importance of their involvement significantly varies. It ranges from the situations where the consent of the victim is a necessary precondition to apply this institution to the situations where the victim is only consulted in the process if it is deemed necessary in order to safeguard his/her interests and rights.

The strongest position of the victim is ensured by the Croatian criminal justice, where the consent of the victim (if there is one) is necessary in order to conclude an agreement between the state attorney and the defendant. This makes an agreement on conditional deferral (or withdrawal) of criminal prosecution a three-sided agreement. It gives the Croatian conditional deferral and withdrawal of prosecution a strong restorative character. ${ }^{109}$ Conditional deferral has a strong restorative and victim-oriented character also in the Austrian law, however, not to the degree present in the Croatian law. In Austria, the consent of the victim is necessary for conditional deferral only if the victim-offender mediation is a measure offered to the defendant by the prosecutor. In all other cases of conditional deferral, the victim must be heard before a decision on conditional deferral of prosecution is made, if it appears necessary to safeguard his/her interests and rights. A comparable situation regarding the rights of the victims of crimes exists in the German law, where the consent of the victim is a necessary precondition for the application of the institution only if the measure offered by the prosecutor is victim-offender mediation. In the English law, there is a duty to consult the victim when deciding whether a conditional caution is appropriate and in determining suitable conditions, however, the consent of the victim is not a necessary precondition for the application of said institution. In Italy, in general, the victim is heard before a decision to discontinue the prosecution, following a fulfilment of obligations by the defendant, has been made. However, the

108 Ivičević Karas, E., op. cit. note 92, p. 428.

109 Ibidem, p. 425. 
consent of the victim is not a necessary precondition for the decision. The same conclusion can be made in relation to the French law.

From the results of the comparative analysis, it derives that the institution of conditional deferral of prosecution has a strong restorative and victim-oriented character in all presented jurisdictions. What remains open is the question which type and degree of involvement of victims is appropriate for this institution. It might be the case that the Croatian system has gone too far in requesting the consent of the victim to reach any agreement between the state attorney and the defendant, notwithstanding the measure which is the object of the agreement. The non-willingness of the victims to consent to such agreements might also be one of the causes for such a scarce practical application of this institution in Croatia.

\section{CONCLUSION}

This paper provided for theoretical and normative analysis of the conditional deferral of criminal prosecution in a comparative perspective as a starting point for identifying key issues of regulation and application of this institution in Croatian criminal procedure law. The comparative analysis pointed out similarities in the regulation of this institution, but also revealed some specifics of Croatian law on conditional deferral and opened question of their adequacy.

First of all, it can be concluded from comparative overview that this institution is reserved for solving minor or petty offences in order to achieve procedural economy and expedite criminal proceedings. However, with regard to the Croatian legislation and practice, there is no conclusive reason as to what the main objective of this institution was from the legislator's perspective. As a result of that, further research should be focussed on the question of why this institution is not used more frequently in the Croatian judicial practice and whether the objectives of this institution should be clearly stated in the legal provisions in order to achieve a better application in practice. The analysis should also try to determine if there are any offences to which this provision does not apply in practice, although they fall under its scope, simply because there is some standardised procedure that the prosecutors resort to when dealing with individual cases.

Conditional deferral as a model of diversion implies a prominent prosecutorial discretion, but the comparative analysis indicates that role and the control of judicial authority is not excluded, though it is usually exercised just as a formality. Considering that the Croatian law abandoned the concept of judicial approval of this consensual form and in the light of these comparative findings, the empirical research should include the questions of whether judicial control is needed and in which form, or if it would just further complicate and discourage the application of this institution in practice.

Regarding the procedural rights of the defendant, comparative analysis indicates that the rights of the defendants are adequately guaranteed in application of this institute. As for the further research, question of providing legal aid to the defendant should be pointed out, as well as the question of usefulness of introducing a provision on informing the defendant about the legal effects of his/her consent and of failure to comply with the agreement. 
With regard to the position of the victim, the results of the comparative analysis have shown the uniqueness of his/her position in the Croatian criminal justice. None of the other jurisdictions requires the consent of the victim for all instances of conditional deferral of criminal prosecution, in fact, the Austrian and German system require it only in situations where the measure offered by the prosecutor is victim-offender mediation. This finding deserves due attention and points to the possibility that such a strong position of the victim may be one of the reasons for the limited application of the institution of conditional deferral in the Croatian legal practice. The following issues also deserve further examination as part of the empirical analysis: adequateness of the position of the victim within the institution and the position of the victim as a dissuasive factor for the application of the institution in practice.

\section{REFERENCES}

1. Boyne, S., Procedural Economy in Pre-Trial Procedure: Developments in Germany and the United States (October 23, 2013, last revised December 1, 2015), Indiana University Robert H. McKinney School of Law Research Paper No. 2013-39, pp. 329- 368.

2. Boyne, S., The German Prosecution Service, Guardians of the Law? Springer Berlin Heidelberg, 2014

3. Caianiello, M., The Italian Public Prosecutor: An Inquisitorial Figure in Adversarial Proceedings? in: Luna, E.; Wade, M. (eds), Transnational perspectives on prosecutorial power, Oxford University Press, 2011

4. Caporotundo, F., L'estinzione del reato per condotte riparatorie: luci ed ombre dell'art. 162-ter c.p., Archivio penale, 2018, n. 1, pp. 1 - 38

5. Carić, M., Skraćeni oblici kaznenog postupka, doktorski rad, Pravni fakultet Sveučilišta u Splitu, Split, 2012

6. Cascini, D. N., Il nuovo art. 162-ter c.p.: esempio di "restorative justice" o istituto orientato ad una semplice funzione deflattiva?, Archivio penale, n. 2, 2017, pp. 1 - 9

7. Coscas-Williams, B., Alberstein, M., A Patchwork of Doors: Accelerated Proceedings in Continental Criminal Justice Systems, New Criminal Law Review, vol. 22, no. 4/2019, pp. 585 - 617

8. Gillièron, G., Public Prosecutors in the United States and Europe A Comparative Analysis with Special Focus on Switzerland, France, and Germany, Springer, 2014

9. Glasnović Gjoni, V., Sirotić, V., Uvjetni odustanak od kaznenog progona i praksa Općinskog suda u PuliPola, Pravni vjesnik, 3-4/2016, pp. 157 - 181

10. Hodgson, H., Guilty Pleas and the Changing Role of the Prosecutor in French Criminal Justice, in Luna, E., Wade, M. (eds.), The Prosecutor in Transnational Perspective, Oxford University Press, 2012, pp. $116-134$

11. Ivičević Karas, E., Consensual Justice in Croatian Criminal Procedural Law: the Need for a Systematic Approach, EU and Comparative Law Issues and Challenges Series (ECLIC) - Issue 4 (2019), pp. 405 $-432$

12. Jehle, J. M., The Function of Public Prosecution within the Criminal Justice System Aim, Approach and Outcome of a European Comparative Study in: Jehle, J.M., Wade, M. (eds), Coping with Overloaded Criminal Justice Systems. The Rise of Prosecutorial Power Across Europe, Springer, 2006

13. Krstulović, A., Nagodbe stranaka u suvremenom kaznenom postupku, Hrvatsko udruženje za kaznene znanosti i praksu, Kaznenopravno-kriminalistička biblioteka Vladimir Bayer, Zagreb, 2007 
14. Radić, I., Sustav maloljetničkih sankcija, doktorski rad, Pravni fakultet Sveučilišta u Zagrebu, Zagreb, 2016.

15. Ruggieri, F., Marcolini, S., Italy in: Toward a Prosecutor for the European Union, Volume 1: A comparative Analysis. Ed. Katalin Ligeti. London: Hart Publishing, 2013

16. Ruggieri, S., Audi Alteram Partem in Criminal Proceedings, Towards a Participatory Understanding of Criminal Justice in Europe and Latin America, Springer International Publishing AG, 2017,

17. Sirotić, V., Uvjetna odgoda kaznenog progona punoljetnog počinitelja kaznenog djela, Hrvatski ljetopis za kazneno pravo i praksu, vol. 19, no. 1/2012, pp. 161 - 207

18. Soubise, L., Guilty Pleas in an Inqusitorial Setting-An Empirical Study of France, Journal of Law and Society, Cardiff University law School, vol. 45, No. 3, September 2018, pp. 398-426

19. Soubise, L., Prosecutorial Discretion and Accountability, A comparative study of France and England and Wales, doctoral thesis, University of Warwick, School of Law Université Lumière Lyon 2, Faculté de droit et de science politique, December 2015

20. Tak, P.J.P., Methods of diversion used by the prosecution services in the Netherlands and other Western European Countries, 135th International senior seminar visiting experts papers, Resource material series No. 74., 2008, pp. 53-64

\section{LIST OF REGULATIONS AND ACTS}

1. Code of Practice for Adult Conditional Cautions: part 3 of the Criminal Justice Act 2003, January 2013

2. Codice di Procedura Penale (Testo coordinato ed aggiornato del D.P.R. 22 settembre 1988, n. 447) Aggiornato al D.L. 17 marzo 2020, n. 18

3. Codice Penale 2020: aggiornato con le ultime modifiche legislative introdotte, da ultimo, dalla L. 14 agosto 2020, n. 113 e dal D.L. 16 luglio 2020, n. 76 (Decreto Semplificazioni); (R.D. 19 ottobre 1930, n. 1398)

4. Conditional Cautioning: Adults - DPP Guidance, Updated 01 November 2019 Legal Guidance

5. Criminal Justice Act 2003, https://www.legislation.gov.uk/ukpga/2003/44/contents

6. Decreto Legislativo 28 agosto 2000, n. 274,"Disposizioni sulla competenza penale del giudice di pace, a norma dell'articolo 14 della legge 24 novembre 1999, n. 468", pubblicato nella Gazzetta Ufficiale n. 234 del 6 ottobre 2000 - Supplemento ordinario n. 166

7. Strafgesetzbuch as published 13 November 1998 (BGBl. I S. 3322), last amended by Article 1 of the Act from 30 November 2020 (BGBl. I S. 2600)

8. Strafprozeßordnung as published on 7 April 1987 (Federal Law Gazette I, p. 1074, 1319), last amended by Article 49 of the Act from 21 December 2020 (Federal Law Gazette I, p. 3096)

9. Zakon o kaznenom postupku, Official Gazette (Narodne novine), no. 152/08, 76/09, 80/11, 91/12 Decision and Ruling of the Constitutional Court of the Republic of Croatia, 143/12, 56/13, 145/13, $152 / 14,70 / 17$, and $126 / 19$ 


\section{WEBSITE REFERENCES}

1. Ferrione, M., L'estinzione del reato per condotte riparatorie art. 162 ter c.p., p. 2. https://www.studiolegalecavallo.com/wp-content/uploads/2018/07/slide-162-ter-Convegno-3_optimize.pdf. Accessed 28.12.2020

2. Izvješće Državnog odvjetništva Republike Hrvatske za 2017. godinu, p. 36, available at: http:// www.dorh.hr/dorh07062018. Accessed 5.1.2021

3. Pierpoint, H., Bennett, T., Evaluation of conditional cautioning: surveys of stakeholders, offenders and victims, 1st February 2005, pp. 10 - 11. https://pure.southwales.ac.uk/en/publications/evaluation-of-conditional-cautions-surveys-of-stakeholders-offenders-and-victims(c47023b9-7d52-492 d-b522-6d8dd3dc2f5d).html. Accessed 28.12.2020 


\section{UVJETNA ODGODA (I ODUSTANAK) OD KAZNENOG PROGONA U NACIONALNOJ I KOMPARATIVNO PRAVNOJ PERSPEKTIVI}

\section{Sažetak}

Uvjetna odgoda (i odustanak) od kaznenog progona tipičan je konsenzualni institut u kaznenom postupku. Obično se primjenjuje u odnosu na lakša kaznena djela s ciljem smanjenja opterećenja sudova i humanizacije postupanja prema počinitelju. Iako je uveden u hrvatski kaznenopravni sustav prije više od 20 godina, nikada nije stekao status važne i široko primjenjivane institucije. Upravo suprotno, u praksi se uvjetna odgoda kaznenog progona gotovo uopće ne primjenjuje. Kako bi identificirali moguće razloge za to na normativnoj razini, autori su proveli poredbenopravnu analizu navedenog instituta. Glavne karakteristike uvjetne odgode kaznenog progona u Republici Hrvatskoj uspoređene su s glavnim obilježjima identičnih ili ekvivalentnih instituta u pet drugih komparativnih pravnih sustava: austrijskom, njemačkom, talijanskom, engleskom, i francuskom. Posebna pozornost u radu posvećena je analizi pet istaknutih pitanja: ciljevima ovog instituta, kaznenim djelima na koja se može primijeniti, ulozi suda, pravima okrivljenika i položaju žrtve.

Ključne riječi: $\quad$ uvjetni odustanak od kaznenog progona, diversion, neformalne sankcije

\section{(c) (1) (\$)}

This work is licensed under a Creative Commons

Attribution-NonCommercial 4.0 International License.

* Dr. sc. Zoran Burić, docent Pravnog fakulteta Sveučilišta u Zagrebu, Trg Republike Hrvatske 14, 10000 Zagreb. E-adresa: zoran. buric@pravo.hr. ORCID: https://orcid.org/0000-0001-5353-8478.

** Dr. sc. Marija Pleić, docentica Pravnog fakulteta Sveučilišta u Splitu, Domovinskog rata 8, 21000 Split. E-adresa: marija.pleic@ pravst.hr. ORCID: https://orcid.org/0000-0001-8868-0079.

*** Dr. sc. Ivana Radić, poslijedoktorandica Pravnog fakulteta Sveučilišta u Splitu, Domovinskog rata 8, 21000 Split. E-adresa: ivana. radic@pravst.hr. ORCID: https://orcid.org/0000-0003-4946-6437. 